\title{
Article \\ Main Molecular Pathways Associated with Copper Tolerance Response in Imperata cylindrica by de novo Transcriptome Assembly
}

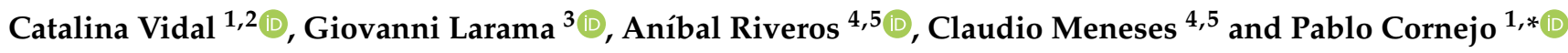 \\ 1 Centro de Investigación en Micorrizas y Sustentabilidad Agroambiental, CIMYSA, \\ Universidad de La Frontera, Avda. Francisco Salazar, Temuco 4780000, Chile; c.vidal04@ufromail.cl \\ 2 Programa de Doctorado en Ciencias de Recursos Naturales, Universidad de La Frontera, \\ Avda. Francisco Salazar, Temuco 4780000, Chile \\ 3 Centro de Modelación y Computación Científica, Universidad de La Frontera, Avda. Francisco Salazar, \\ Temuco 4780000, Chile; giovanni.larama@ufrontera.cl \\ 4 Centro de Biotecnología Vegetal, Facultad de Ciencias de la Vida, Universidad Andrés Bello, República 330, \\ Santiago 8370186, Chile; a.riverosorellana@uandresbello.edu (A.R.); claudio.meneses@unab.cl (C.M.) \\ 5 FONDAP Center for Genome Regulation, Facultad de Ciencias de la Vida, Universidad Andrés Bello, \\ República 330, Santiago 8370186, Chile \\ * Correspondence: pablo.cornejo@ufrontera.cl
}

Citation: Vidal, C.; Larama, G.; Riveros, A.; Meneses, C.; Cornejo, P. Main Molecular Pathways Associated with Copper Tolerance Response in Imperata cylindrica by de novo Transcriptome Assembly. Plants 2021, 10, 357. https://doi.org/ $10.3390 /$ plants10020357

Academic Editor: Maurizio Cocucci

Received: 29 December 2020

Accepted: 7 February 2021

Published: 13 February 2021

Publisher's Note: MDPI stays neutral with regard to jurisdictional claims in published maps and institutional affiliations.

Copyright: (c) 2021 by the authors. Licensee MDPI, Basel, Switzerland. This article is an open access article distributed under the terms and conditions of the Creative Commons Attribution (CC BY) license (https:// creativecommons.org/licenses/by/ $4.0 /)$.
Abstract: The metallophyte Imperata cylindrica inhabits copper $(\mathrm{Cu})$ polluted soils in large areas from Central Chile. Here, we subjected clonal vegetative plantlets to $300 \mathrm{mg} \mathrm{Cu} \mathrm{kg}^{-1}$ of substrate for 21 days to identify the main molecular pathways involved in the response to Cu stress. Transcriptomic analyses were performed for shoots and roots, with and without Cu supply. RNA-Seq and de novo transcriptome assembly were performed to identify the gene response associated with molecular mechanisms of $\mathrm{Cu}$ tolerance in I. cylindrica. De novo transcriptome revealed a total of 200,521 transcripts (1777 bp) comprising 91\% complete ultra-conserved genes in the eukaryote and Plantae database. The differentially expressed genes (DEGs) in roots were 7386, with 3558 of them being up-regulated and the other 3828 down-regulated. The transcriptome response in shoots was significantly less, showing only 13 up-regulated and 23 down-regulated genes. Interestingly, DEGs mainly related with actin and cytoskeleton formation, and to a minor degree, some DEGs associated with metal transporters and superoxide dismutase activity in root tissues were found. These transcriptomic results suggest that cytoskeleton could be acting as a mechanism of Cu-binding in the root, resulting in a high $\mathrm{Cu}$ tolerance response in this metallophyte, which deserve to be analyzed ultra-structurally. Our study contributes to reinforcing the potential of I. cylindrica as a candidate plant species to be used as a phytoremediation agent in $\mathrm{Cu}$-contaminated environments.

Keywords: Cu tolerance; Cu toxicity; de novo transcriptome; metallophyte; RNA-Seq

\section{Introduction}

Soil degradation originating from exacerbated mining activity has become a global environmental problem [1,2], which need to be solved in the short term. In Chile, Copper $(\mathrm{Cu})$ mining has produced a strong deleterious impact, with large areas of soils contaminated with potentially toxic elements (PTEs), which highlights large amounts of Cu [3-5]. Although $\mathrm{Cu}$ is an essential micronutrient for plants and this limit is above $20-30 \mathrm{mg} \mathrm{kg}^{-1}$ [6], high concentrations in cells can be extremely toxic. The $\mathrm{Cu}$ toxicity is due to its ability to alter the enzyme activity and protein functionality, and also by inducing the deficiencies of other nutrients, but mainly by the generation of oxidative damage in the main macromolecules [7]. Moreover, at the rhizosphere $\mathrm{Cu}$ can disrupt soil characteristics and the microbiota properties, producing a loss of ecological functionality [8-10]. 
Despite the above, there are some plant populations capable to survive in soils with high levels of PTEs, known as metallophytes. These species can survive under high $\mathrm{Cu}$ soil levels; therefore, they can be implemented in phytoremediation processes [11,12]. Among metallophyte naturally growing in $\mathrm{Cu}$-contaminated soils in central areas from Chile, Imperata cylindrica is a common inhabitant in the Puchuncaví Valley, which is a place recognized as one of the highest metal-polluted sites in the country. This species has been characterized in other latitudes as an iron hyperaccumulator $[13,14]$; nevertheless, its $\mathrm{Cu}$ tolerance capacity has not been deeply studied. Imperata cylindrica is a perennial grass widespread in some regions of Asia and other latitudes worldwide, being used for animal feed, roofing traditional houses, erosion control and also medicinal purposes $[15,16]$. I. cylindrica preferentially propagates through vegetative rhizomes [17]. This species has become an invasive weed to crops; however, in the last decades, the great potential of perennial grasses has also been evaluated as a raw material for use in the generation of biofuel and bioenergy, due to the fast growth and low cost of maintenance [18]. Some previous studies have shown the ability of I. cylindrica to exude high levels of low molecular weight organic acids [19] and accumulate this element in its rhizomes over $300 \mathrm{mg} \mathrm{Cu} \mathrm{kg}^{-1}$ of dry weight. Moreover, a recent study through scanning electron microscopy and energy dispersive $\mathrm{X}$-ray spectrometer detector confirmed the preferential $\mathrm{Cu}$ accumulation in root organs by I. cylindrica [20].

Among the principal mechanisms of $\mathrm{Cu}$ tolerance in plants, highlights are translocation by means of membrane transporters and specialized chaperones [21], immobilization in the cell wall [22], complexation with chelating agents (phytochelatins, metallothioneins, amino acids, and organic acids in the cytosol) [23,24], and sequestration into vacuole, principally in root organs [25]. However, to know and deeply understand the mechanisms involved in the $\mathrm{Cu}$ tolerance by metallophytes can be an interesting way to improve biotechnological process as phytoremediation of $\mathrm{Cu}$-contaminated environments.

In the last decade, the use of Next Generation Sequencing (NGS) technologies has become widespread, and has contributed to the characterization of the response to various types of stress in all kinds of organisms [26,27]. This revolutionary approach allows obtaining great volume of information from the nucleotide sequence of an individual, being able to shows its gene expression response. The survival of an organism under different environmental stressors is mainly due to its ability to adapt, and this crucial role is mostly fulfilled by the process of gene regulation $[28,29]$. Based on the above, in this study, we aimed to characterize the $\mathrm{Cu}$ tolerance response of $\mathrm{I}$. cylindrica by means of the shifts in its transcriptome and glimpse the molecular mechanisms of $\mathrm{Cu}$-root accumulation based on the gene response. This knowledge can provide relevant information when considering the use of this species in $\mathrm{Cu}$-phytoremediation needed for extent surfaces in north and central Chile, where $\mathrm{Cu}$ mining is the most important economic activity.

\section{Results}

\subsection{Biomass Production and Localization of $\mathrm{Cu}$ in Tissue}

The $\mathrm{Cu}$ applied in the growth substrate of I. cylindrica plants generated a significant decrease in the fresh biomass production in both shoots and roots compared to the control conditions (Figure 1A,B) after 21 days of the treatment. Moreover, the $\mathrm{Cu}$ accumulated was two to four times higher in the treatment with $\mathrm{Cu}$ addition, compared with the control without $\mathrm{Cu}$ addition (Figure 1C,D). The $\mathrm{Cu}$ localization in tissue of $\mathrm{I}$. cylindrica through scanning electron microscopy (SEM) coupled to Energy-dispersive X-ray analysis (EDX) spectra allowed us to identify the presence of $\mathrm{Cu}$ in root tissues of plants exposed to treatment with this metal (Figure 2). On the contrary, the presence of $\mathrm{Cu}$ in shoots was not visualized irrespective of the $\mathrm{Cu}$ treatment. 
A

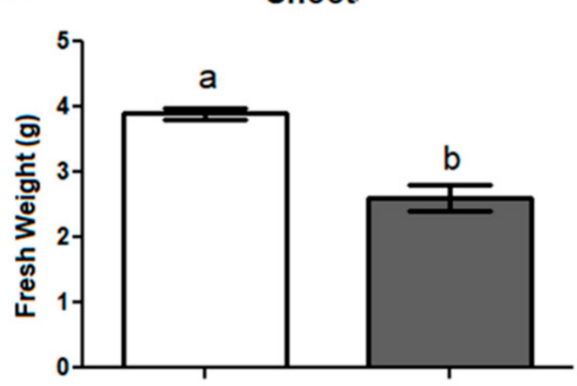

C

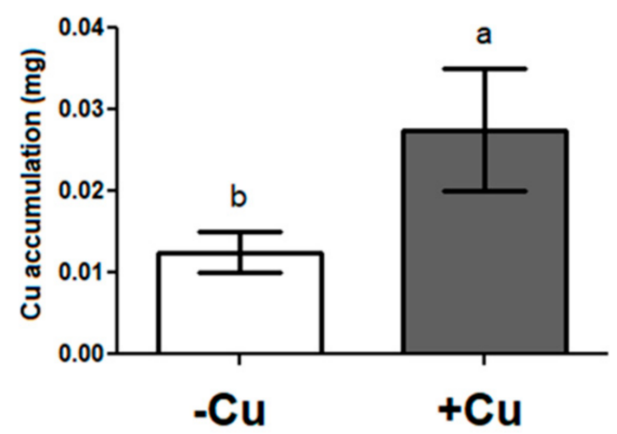

B

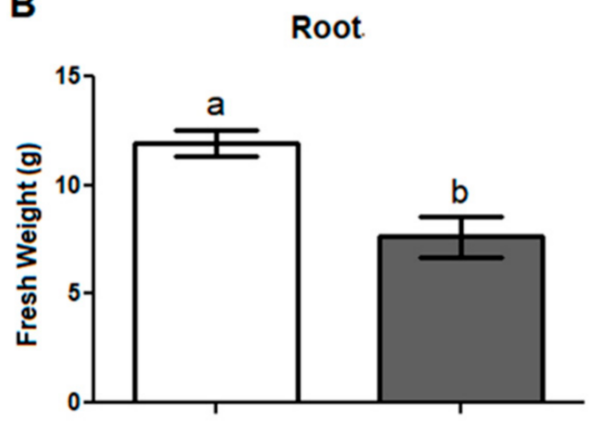

D

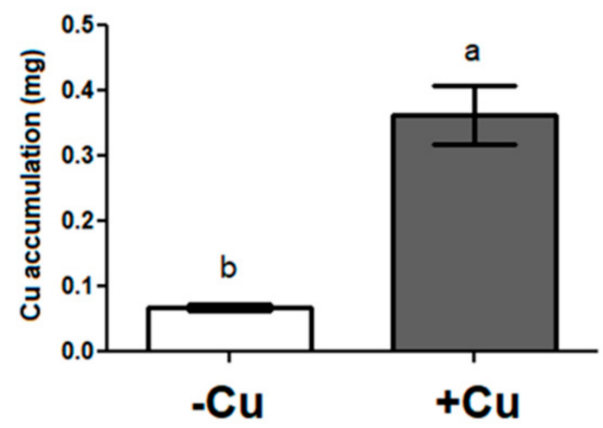

Figure 1. Biomass production ( $\mathrm{g}$ fresh weight per experimental unit) of Imperata cylindrica: (A) shoots biomass, (B) root biomass; and $\mathrm{Cu}$ accumulation in (C) shoot and (D) root. $-\mathrm{Cu}$, treatment without $\mathrm{Cu}$ applied, and $+\mathrm{Cu}$ treatment with addition of $300 \mathrm{mg} \mathrm{Cu} \mathrm{kg}^{-1}$ substrate. Different lowercase letters indicate differences according to t-tests for independent samples $(p<0.05)$. Data are expressed as mean $\pm \mathrm{SE}, n=4$.

\subsection{Illumina Sequencing and De novo Transcriptome Assembly}

To characterize the transcriptome responses of I. cylindrica under Cu stress, 15 cDNA libraries were sequenced, including eight constructed from shoots and seven from roots. A total of 371,336 paired-end reads were obtained. The reads were trimmed and filtered to remove low-quality reads, resulting in a total of 347,207 high-quality reads (HQR). The HQR were concatenated to assembly the I. cylindrica transcriptome using the Trinity software. The resulting contigs were clustered to remove those highly redundant ( $>95 \%$ similarity), being identified 200,521 contigs with an N50 value of 1918 bp (Table 1). The transcripts obtained were aligned to the SwissProt database, being obtained 117,238 annotated genes, corresponding to $58 \%$ of the total I. cylindrica contigs. To estimate the quality of the I. cylindrica transcriptome, we searched a set of highly-conserved orthologous genes on the Benchmarking Universal Single-Copy Orthologs (BUSCO) database. A yield of 1375 BUSCO genes, 1259 complete (91.5\%), 85 fragmented (6.2\%), and 31 missed (2.3\%) genes were found in the I. cylindrica transcriptome (Table 2).

Table 1. De novo transcriptome assembly of Imperata cylindrica by RNA-Seq.

\begin{tabular}{cc}
\hline \multicolumn{1}{c}{ Metric I. cylindrica Transcriptome } \\
\hline Trinity transcripts & 200,521 \\
Trinity "genes" & 113,137 \\
GC (\%) & 50 \\
Contig N50 (bp) & 1918 \\
Median contig length (bp) & 978 \\
Average contig (bp) & 1377 \\
Total assembled bases & $276,047,337$ \\
Blastx Hit SwissProt & $(58 \%) 117,238$ \\
\hline
\end{tabular}



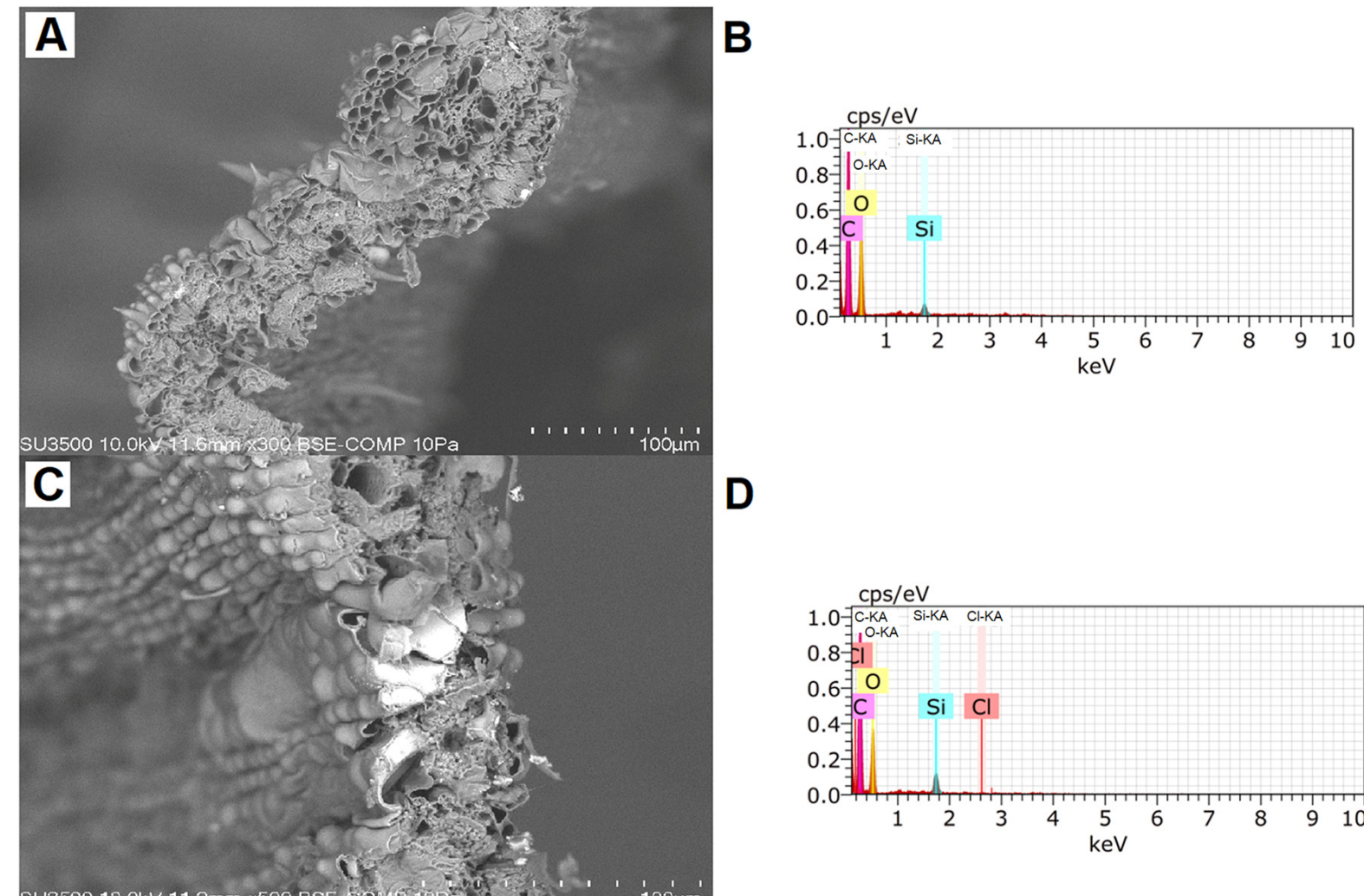

\section{D}
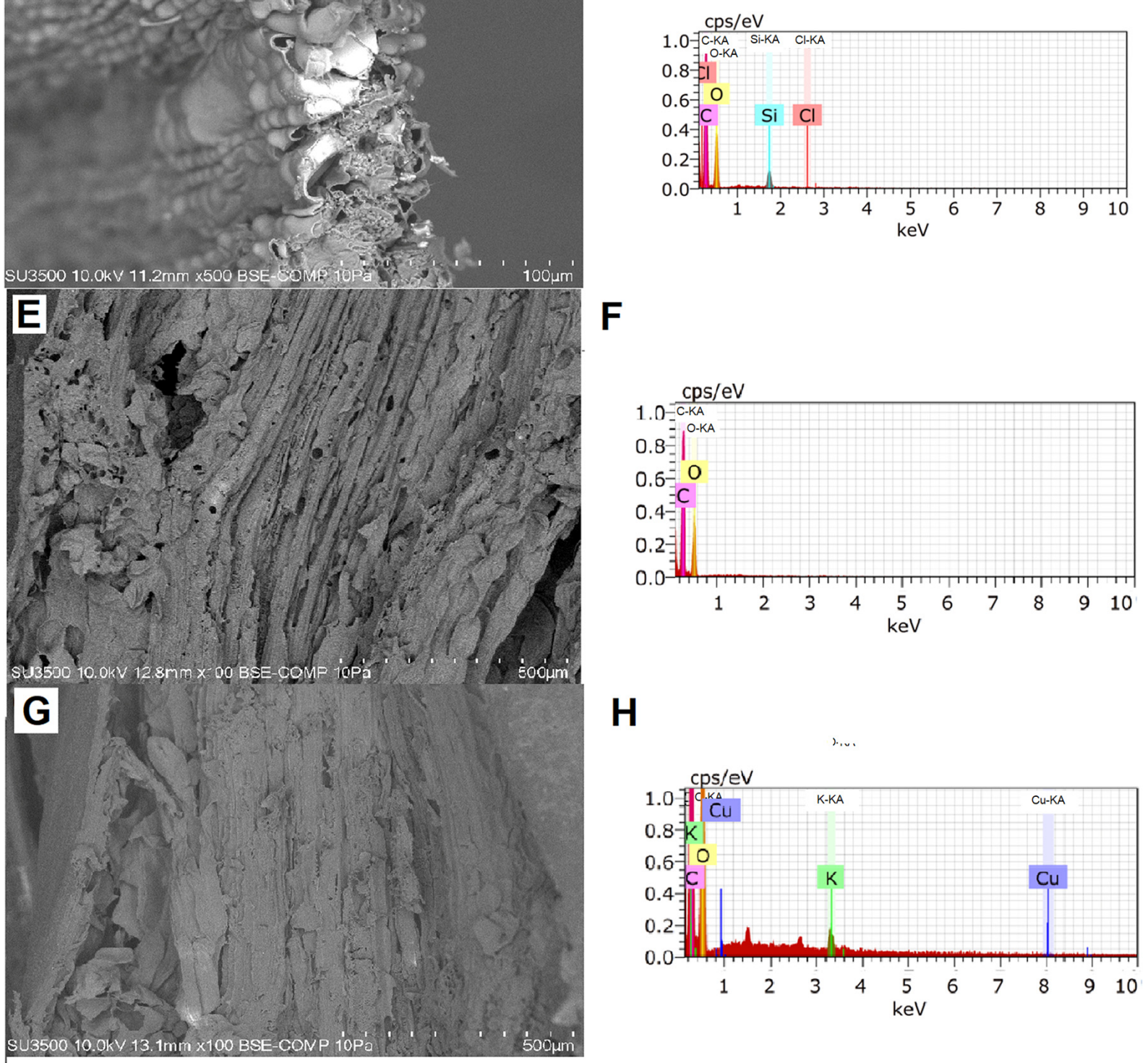

Figure 2. Scanning electron microscopy (SEM) in transversal sections of Imperata cylindrica shoot (A) without Cu addition, (B) Energy-dispersive X-ray (EDX) spectra without $\mathrm{Cu}$ addition, (C) SEM of shoot with Cu addition $\left(300 \mathrm{mg} \mathrm{kg}^{-1}\right)$, and (D) EDX spectra with Cu addition. SEM in longitudinal sections of I. cylindrica root (E) without Cu addition, (F) EDX spectra without $\mathrm{Cu}$ addition, $(\mathbf{G})$ SEM of root with $\mathrm{Cu}$ addition $\left(300 \mathrm{mg} \mathrm{kg}^{-1}\right)$, and $(\mathbf{H})$ EDX spectra with Cu addition. 
Table 2. Validation of the de novo transcriptome assembly of Imperata cylindrica.

\begin{tabular}{ccc}
\hline Summary of Benchmarking Universal Single-Copy & Orthologs (BUSCO) Statistics \\
\hline Complete BUSCOs & 1259 & $91.5 \%$ \\
Complete and single-copy BUSCOs & 560 & $40.7 \%$ \\
Complete and duplicated BUSCOs & 699 & $50.8 \%$ \\
Fragmented BUSCOs & 85 & $6.2 \%$ \\
Missing BUSCOs & 31 & $2.3 \%$ \\
Total BUSCO genes & 1375 & $100.0 \%$ \\
\hline
\end{tabular}

* Database: embriophyte_odb10.

\subsection{Multivariate Analysis}

The PCA analysis evidenced the formation of three highly independent groups according to the distribution of the samples, where the shoot and root samples were separated by PC1, which explained $71.6 \%$ of the variation in the samples. Moreover, PC2 only separated the root samples according to the $\mathrm{Cu}$ treatment, explaining $9.1 \%$ of the total experimental variability. The first group included the samples of shoots both with and without $\mathrm{Cu}$ treatment, the second group collected the control root samples, while the third group included the root samples supplied with $\mathrm{Cu}$ (Figure 3).

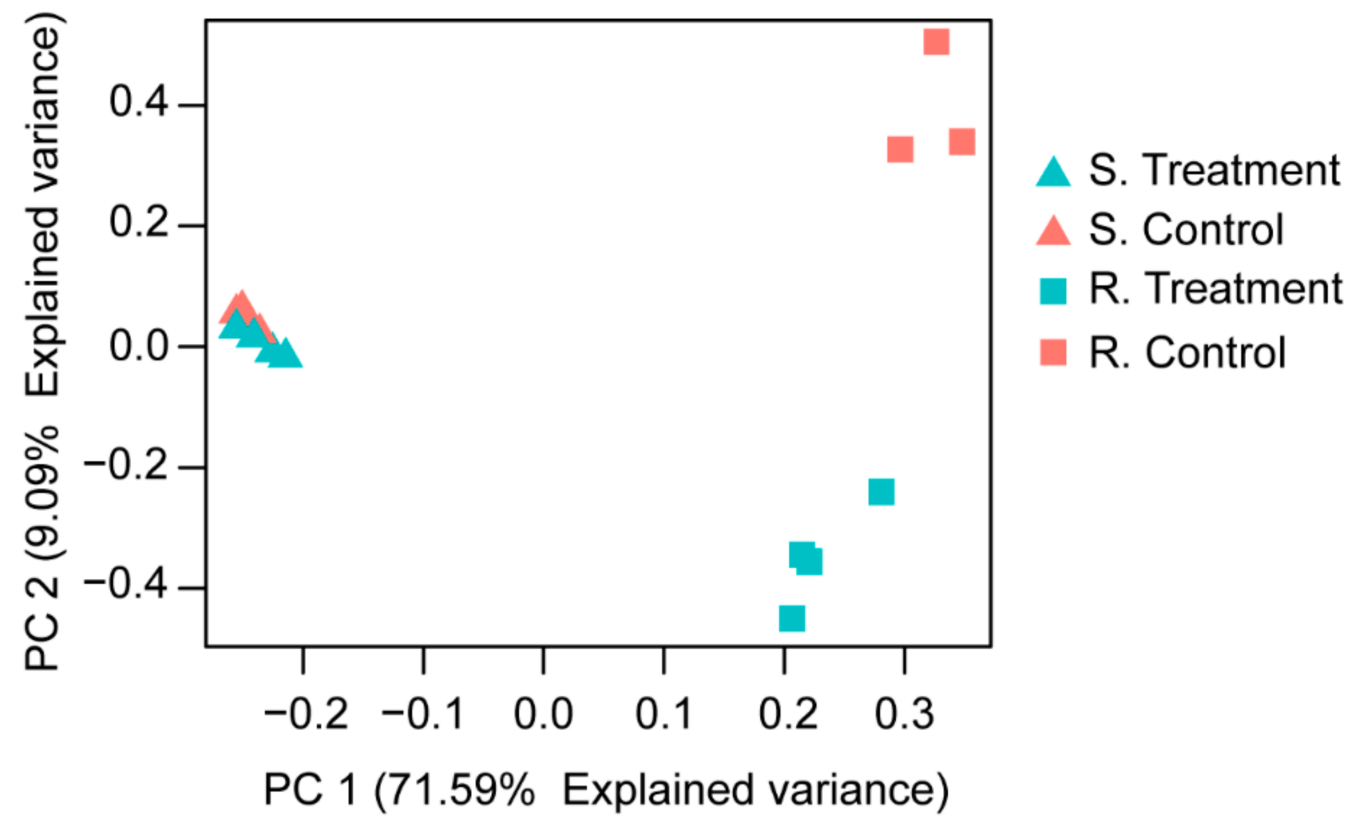

Figure 3. Principal Component Analysis of Imperata cylindrica in shoots and roots samples. The control treatment was established without $\mathrm{Cu}$ addition, while the treatment consisted in the addition of $300 \mathrm{mg} \mathrm{Cu} \mathrm{kg}^{-1}$ substrate.

\subsection{Differential Expression Analysis}

The differential expression analysis, which compared the control condition with the $\mathrm{Cu}$ addition, showed a high contrast in the response of the root organs regarding the shoots. In roots, a total of 7386 genes were differentially expressed, of which 3558 were upregulated and 3828 down-regulated. Noticeably, in shoots, only 36 genes were differentially expressed, of which 13 were up-regulated and 23 down-regulated. A gene ontology analysis was performed with all differentially expressed genes (DEG) in the plant. This analysis classified the genes based in their functions on three general groups: (i) molecular function, (ii) biological process, and (iii) cellular component. Within the first group, only "structural molecule activity" presented a higher number of up-regulated than down-regulated genes. The other categories showed a higher number of down-regulated genes, highlighting 
"catalytic activity" and "transporter activity." The genes associated with biological processes presented a higher number of down-regulated genes in all the subgroups. These results were evidenced mainly in the categories of "cellular process," "metabolic process," and "localization." Finally, the group of cellular components concentrated the largest number of DEGs, where all the categories had more down-regulated than up-regulated genes (Figure 4).

Down-regulated

Transcription regulator activity

Catalytic activity

Molecular transducer activity

Structural molecule activity

Translation regulator activity

Binding

Transporter activity

Molecular function regulator

Developmental process

Reproduction

Cell. comp. organization or biogenesis

Cellular process

Metabolic process

Multi-organism process

BP

CC
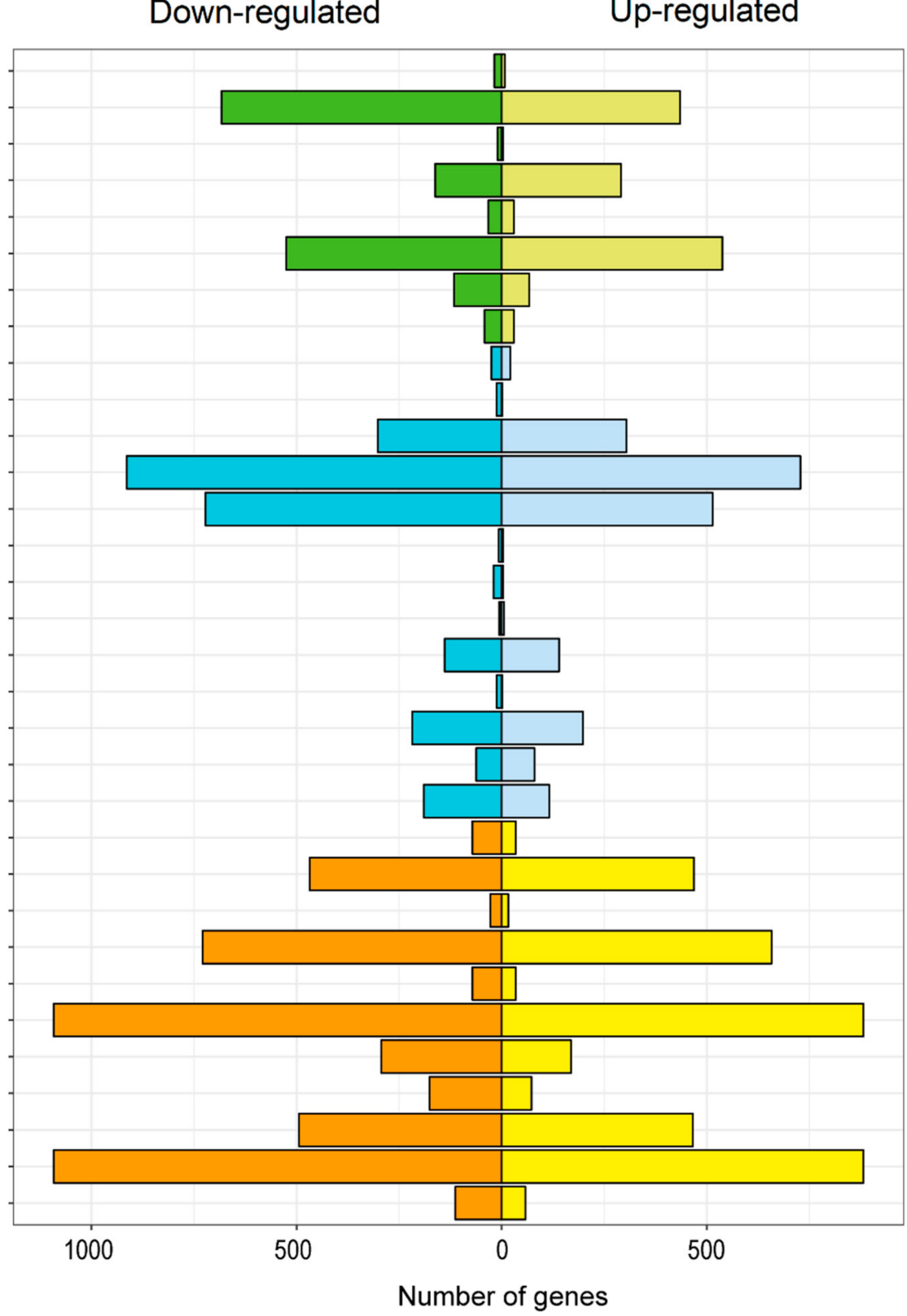

Figure 4. Gene ontology distribution in de novo transcriptome of Imperata cylindrica according to level 1 categories: Cellular Component (CC), Biological Process (BP), and Molecular Function (MF). Genes are differentially expressed in treatment compared to control conditions.

A second analysis was performed to group the DEGs according to the class of protein to which they belong. According to the protein analysis through evolutionary relationships (PHANTER) classification system, the largest number of genes up-regulated in I. cylindrica corresponded to "translational protein," "metabolite interconversion enzyme," "protein modified enzyme," "cytoskeletal protein," and "transporter." Otherwise, the down-regulated genes were a larger group than the up-regulated, with "metabolite in- 
terconversion enzyme" and "translational protein" being the most abundant (Figure 5). The search of DEGs in I. cylindrica shoots in the SwissProt database yielded only one upregulated gene; cysteine-rich receptor-like protein kinase 10. Among the down-regulated gene group were noticeable the protein sulfur deficiency-induced 1, phosphate transporter PHO1-3, inorganic phosphate transporter 1-11, vacuolar iron transporter homolog 1, pectin acetylesterase 7, and bidirectional sugar transporter Sweet3a (Table 3). In the case of DEGs explored in root organs, many genes with described functionality were obtained, both for up-regulated and down-regulated genes (Table 4). We focused on those genes involved in $\mathrm{Cu}$ and metal tolerance response processes. Among them are superoxide dismutase (SOD) [Cu-Zn], SOD [Cu-Zn] 2, and SOD [Fe], mainly associated with the response against oxidative stress. Probable copper-transporting ATPase HMA5 and Hephaestin-like protein were also identified, both involved in the process of $\mathrm{Cu}$ ion transport. Additionally, a great number of genes involved in the cytoskeleton conformation (over 70) were up-regulated, with the most abundant being actin-1, actobindin-A, coactosin, and tubulin beta chain. On the contrary, among the down-regulated genes, several genes were involved both in the $\mathrm{Cu}$ and metal tolerance response and in the cytoskeleton conformation, namely: SOD [Mn] mitochondrial; extracellular SOD [Cu-Zn]; $\mathrm{Cu}$ transport protein ATOX1; Actin, muscle; Actin; Actin-1; and Actin-87E (Table 4).

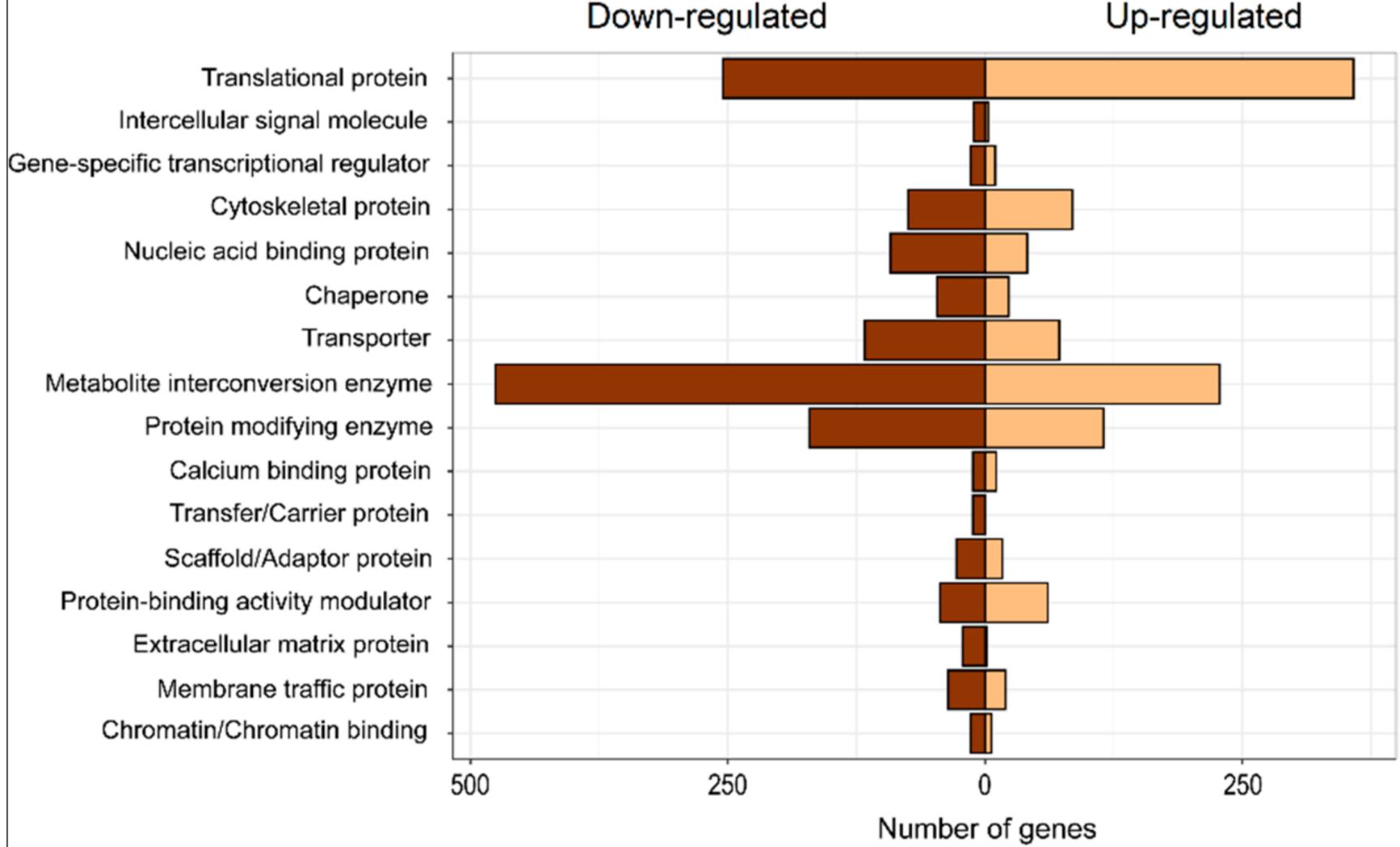

Figure 5. Distribution of differentially expressed genes according to the protein analysis through evolutionary relationships (PHANTER) classification system in plants of Imperata cylindrica. The bars show the number of genes encoding for each functional class. Genes are differentially expressed in treatment with $\mathrm{Cu}$ addition $\left(300 \mathrm{mg} \mathrm{Cu} \mathrm{kg}^{-1}\right.$ substrate) compared to control condition without $\mathrm{Cu}$ addition. 


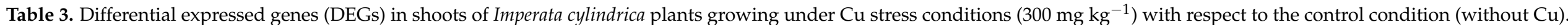

\begin{tabular}{|c|c|c|c|c|c|}
\hline Gene Encoding for & Ontology & FPKM Control & FPKM Treatment & Fold Change (FC) & $p$-Value \\
\hline Cysteine-rich receptor-like protein kinase 10 & MF: ATP binding (GO:0005524) & 0 & 233.66 & 10.61 & $7.80 \times 10^{-22}$ \\
\hline Protein SULFUR DEFICIENCY-INDUCED 1 & BP: regulation of sulfur utilization (GO:0006792) & 76.03 & 1.06 & -5.11 & $9.00 \times 10^{-5}$ \\
\hline Protein SULFUR DEFICIENCY-INDUCED 1 & BP: cellular response to sulfur starvation (GO:0010438) & 1817.86 & 229.38 & -7.69 & $2.70 \times 10^{-11}$ \\
\hline Phosphate transporter PHO1-3 & PB: phosphate ion transport (GO:0006817) & 98.79 & 11.16 & -4.92 & $1.80 \times 10^{-4}$ \\
\hline Inorganic phosphate transporter $1-11$ & BP: phosphate ion transport (GO:0006817) & 2162.05 & 269.6 & -4.69 & $4.30 \times 10^{-4}$ \\
\hline Vacuolar iron transporter homolog 1 & BP: intracellular sequestering of iron ion (GO:0006880) & 44.07 & 0 & -7.57 & $5.70 \times 10^{-11}$ \\
\hline GDP-L-galactose phosphorylase 2 & MF: hydrolase activity (GO:0016787) & 9153.18 & 1541.18 & -6.73 & $1.80 \times 10^{-8}$ \\
\hline Pectin acetylesterase 7 & BP: cell wall organization (GO:0071555) & 211.39 & 13.83 & -4.44 & $1.10 \times 10^{-3}$ \\
\hline Bidirectional sugar transporter SWEET3a & MF: sugar transmembrane transporter activity (GO:0051119) & 104.55 & 3.94 & -4.58 & $6.40 \times 10^{-4}$ \\
\hline RNA exonuclease 4 & PB: rRNA processing (GO:0006364) & 53.93 & 5.02 & -4.65 & $4.9 \times 10^{-4}$ \\
\hline
\end{tabular}

FPKM = Fragments per kilobase of transcript per million mapped reads. FC = Fold Change, based on the $\log _{2}$ FC value. 


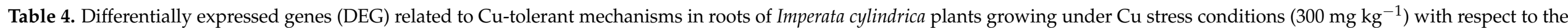
control condition (without $\mathrm{Cu}$ ).

\begin{tabular}{|c|c|c|c|c|c|}
\hline Gene Encoding for & Ontology & FPKM Control & FPKM Treatment & Fold Change (FC) & $p$-Value \\
\hline Superoxide dismutase $[\mathrm{Mn}]$, mitochondrial & PB: removal of superoxide radicals (GO:0019430) & 94.74 & 0 & -4.08 & $6.79 \times 10^{-4}$ \\
\hline Extracellular superoxide dismutase [Cu-Zn] & PB: removal of superoxide radicals (GO:0019430) & 77.17 & 0 & -3.82 & $1.62 \times 10^{-3}$ \\
\hline Superoxide dismutase [Cu-Zn] & PB: removal of superoxide radicals (GO:0019430) & 0.55 & 25.13 & 3.90 & $1.3 \times 10^{-3}$ \\
\hline Superoxide dismutase $[\mathrm{Cu}-\mathrm{Zn}] 2$ & PB: removal of superoxide radicals (GO:0019430) & 6.68 & 82.63 & 4.36 & $2.5 \times 10^{-4}$ \\
\hline Superoxide dismutase $[\mathrm{Fe}]$ & MF: superoxide dismutase activity (GO:0004784) & 12.32 & 82.56 & 4.17 & $5.0 \times 10^{-4}$ \\
\hline Copper transport protein ATOX1 & BP: cellular copper ion homeostasis (GO:0006878) & 47.45 & 0 & -3.53 & $4.07 \times 10^{-3}$ \\
\hline Hephaestin-like protein & BP:copper ion transport (GO:0006825) & 2.68 & 36.63 & 5.17 & $9.6 \times 10^{-6}$ \\
\hline Probable copper-transporting ATPase HMA5 & BP:detoxification of copper ion (GO:0010273) & 1.72 & 23.09 & 3.95 & $1.1 \times 10^{-3}$ \\
\hline Protein NBR1 homolog & BP:protein transport (GO:0015031) & 9.18 & 100.88 & 7.02 & $5.0 \times 10^{-10}$ \\
\hline $\mathrm{ABC}$ transporter $\mathrm{C}$ family member 8 & BP: transmembrane transport (GO:0055085) & 5.41 & 34.58 & 3.88 & $1.3 \times 10^{-3}$ \\
\hline Actin, muscle & CC: cytoskeleton (GO:0005856) & 92.68 & 3.17 & -4.37 & $2.34 \times 10^{-4}$ \\
\hline Actin & CC: cytoskeleton (GO:0005856) & 7459.58 & 1584.51 & -4.14 & $5.38 \times 10^{-4}$ \\
\hline Actin-1 & CC: cytoskeleton (GO:0005856) & 162.63 & 18.93 & -3.80 & $1.72 \times 10^{-3}$ \\
\hline Actin-87E & CC: cytoskeleton (GO:0005856) & 1441.51 & 0.49 & -6.70 & $3.39 \times 10^{-9}$ \\
\hline Actin-1 & CC: cytoskeleton (GO:0005856) & 13.44 & 218.38 & 4.98 & $2.2 \times 10^{-5}$ \\
\hline Actin-related protein 2 & MF:actin binding (GO:0003779) & 0.55 & 46.29 & 6.28 & $4.0 \times 10^{-8}$ \\
\hline Actobindin-A & MF:actin binding (GO:0003779) & 5.49 & 234.97 & 6.19 & $6.6 \times 10^{-8}$ \\
\hline
\end{tabular}

FPKM = Fragments per kilobase of transcript per million mapped reads. FC = Fold Change, based on the $\log _{2}$ FC value. 


\section{Discussion}

High levels of $\mathrm{Cu}$ affect key processes in plant development and growth, including the uptake of micro- and macronutrients, the reduction of pigment contents altering the photosynthesis process, and root expansion [30,31]. However, some plant species have a wide range of mechanisms to deal with metal stress and stop or at least diminish its deleterious effects on cellular processes [32]. Our study evidenced a noticeable difference in the transcriptomic response of root organs in comparison to shoot tissues in I. cylindrica growing under $\mathrm{Cu}$ stress conditions. Our results support that the root and rhizome are the main organ responsible for the tolerance to toxic $\mathrm{Cu}$ levels. Moreover, the PC analysis evidenced the homogeneity in the root organs according to the $\mathrm{Cu}$ treatment, which allowed it to separate into two clearly defined groups for $\mathrm{Cu}$ supply and control condition. This also supports the further homogeneity in the shoot samples irrespective of the $\mathrm{Cu}$ treatment (Figures 2 and 3). These results are in agreement with previous report by Vidal et al. [20], where high concentrations of $\mathrm{Cu}\left(>300 \mathrm{mg} \mathrm{kg}^{-1} \mathrm{DW}\right)$ were reported in root organs of I. cylindrica, compared to values about 10-fold lower in shoot tissues. The $\mathrm{Cu}$ uptake and accumulation firstly occurs at a great magnitude in the root organs, therefore producing a low rate of translocation to shoots [33,34]. Previous reports on Elsholtzia splendens and Bambusoideae plants showed that the majority of absorbed $\mathrm{Cu}$ is accumulated nearby the root rhizodermis as a layer $[35,36]$. Meanwhile, other studies in Oryza sativa and Commelina communis evidenced a major $\mathrm{Cu}$ accumulation in the vascular tissues at the root level [37,38].

Here, DEGs in shoots suggested that high levels of $\mathrm{Cu}$ in I. cylindrica rhizosphere generate principally a down-regulation of genes involved in transport processes. Among them is the gene encoding for protein sulfur deficiency-induced 1, involved in the utilization of stored sulfate under sulfur-deficient conditions [39]. Additionally, genes encoding for phosphate transporter PHO1-3, inorganic phosphate transporter 1-11, were downregulated. In the case of genes encoding for phosphate transporters, plants can induce the overproduction of these membrane proteins to facilitate the introduction of inorganic phosphate (Pi) from the rhizosphere and thus satisfy biological demand during signaling and energy processes [40]. In addition, gene encoding for vacuolar iron transporter homolog 1 was also down-regulated in the $\mathrm{Cu}$ treatment. These results suggest that excess of $\mathrm{Cu}$ in plants produces an alteration in the transport of other essential nutrients mainly in the shoots. Noticeably, in the $\mathrm{Cu}$ time exposure here used (21 days) typical deleterious damages (such as chlorosis, necrosis, and death, among others) associated to nutrient deficiency were not observed. The architecture of this species could be in part responsible for this visual observation, since the presence of rhizomes can allow the preferential $\mathrm{Cu}$ accumulation in underground tissues and concomitantly act as a source of nutrients for the functioning of the shoots. However, this hypothesis must be further studied, including a series of chemical, morphological, omics, and ultrastructural tools to decipher whether the acquisition of nutrients by the plant increased or decreased under $\mathrm{Cu}$ stress.

Exposure to toxic $\mathrm{Cu}$ levels induces the formation of reactive oxygen species (ROS) inside plant cells, which leads to an imbalance in red-ox homeostasis [41,42]. The accumulation of ROS generates increasing oxidation of tissue components that can switch on a multitude of damaging effects, including injury of membranes, nucleic acids, proteins, and carbohydrates [43], finally causing the death of the organism [6,44]. However, plants can face these negative effects through intracellular mechanisms, being the antioxidant mechanisms the first line of action against this stress.

A response of down-regulated and up-regulated genes with SOD function was evidenced in the root transcriptome of I. cylindrica when the $\mathrm{Cu}$ treatment was used in the substrate. The presence of SOD is a common response to oxidative stress in all the plants, where these antioxidant enzymes act in the control over cellular level of free radicals [45,46], decreasing the cellular damage caused in this case by the $\mathrm{Cu}$ ions excess and alleviating $\mathrm{Cu}$ toxicity [47]. The down-regulated genes here found were the SOD [Mn], which codifies for an enzyme with mitochondrial localization, and the extracellular SOD [Cu-Zn]. 
Contrastingly, the SOD up-regulated genes identified by $\mathrm{Cu}$ addition were the cytosolic SOD $[\mathrm{Cu} / \mathrm{Zn}]$ and the chloroplastic SOD [Fe] [48]. These results suggest the presence of an efficient mechanism of regulation involving both an intra- and extra-cellular level, mainly associated with the $\mathrm{Cu}$ localization, which could be mediated by the damage generated in each individual organelle. Meanwhile, contrarily to the regulation of ion transporter genes that occurred in shoots, in I. cylindrica root was evidenced a variety of these up-regulated genes, and only one down-regulated gene was identified. Genes encoding for Hephaestin-like protein and $A B C$ transporter $C$ family member 8 were part of this group. Hephaestin-like protein may function as a ferroxidase and may be involved in $\mathrm{Cu}$ transport and homeostasis; moreover, $\mathrm{ABC}$ transporter belongs to a large protein family that in plants are involved in the transport of a range of essential and PTEs (as $\left.\mathrm{Cu}^{+2}, \mathrm{Zn}^{+2}, \mathrm{Cd}^{+2}, \mathrm{~Pb}^{+2}\right)$ across cell membranes [7,34,49]. The Probable copper-transporting ATPase HMA5, in turn, plays a key role in transmembrane $\mathrm{Cu}$ transport and is specifically induced by $\mathrm{Cu}$ in plants [50]. Moreover, studies in Oryza sativa demonstrated that this gene is involved in the loading of $\mathrm{Cu}$ to the xylem in roots and other organs [51], playing a key role in the $\mathrm{Cu}$ accumulation in root organs, which agrees with other observations by Vidal et al. [20]. The joint up-regulation of these genes demonstrated their importance in the $\mathrm{Cu}$ detoxification process in the plant roots, since these transporters take $\mathrm{Cu}$ ions from the soil, further distributing among plant organs and finally compartmentalize into subcellular organelles in the cell [52].

Among the DEGs in the root, an abundant group was formed by genes associated with the conformation and regulation of the cytoskeleton. This battery of genes included: actin, actin-1, actin-87E, actin related protein 2, and actobindin-A, among more than 100 other genes involved in structural function in the cell. Actin is the protein constituting the cytoskeleton microfilaments. Exposure to higher $\mathrm{Cu}$ levels can interfere with tyrosine phosphorylation of actin molecules, which is one of mechanisms of actin filaments depolymerization [53]. Meanwhile, the cytoskeletal microtubules composed are dynamic and their polymerization/depolymerization cycles are affected by many factors, such as temperature, drugs, metallic ions presence, or even other compounds able to increase the ROS as herbicides [54-56]. Studies about the effect of metals on the conformation of the mussel hematocyte cytoskeleton suggested that metals such as $\mathrm{Cd}$ and $\mathrm{Cu}$ could directly bind to cytoskeleton proteins followed by denaturation [57]. Another study by Jia et al. [58] showed how the $\mathrm{Cu}$-oxide nanoparticles altered the cytoskeleton conformation in roots of Arabidopsis thaliana. In this case, the Cu-nanoparticles could conjugate with actin protein, inhibiting actin polymerization and concomitantly promoting its depolymerization. These antecedents could explain the high number of DEGs associated with the cytoskeleton, which would initially be acting as a target site of $\mathrm{Cu}$-binding and then would be fragmented. The latter can generate the need for resynthesize these molecules and to ensure the structural and functional integrity of the cell. In this way, Xu et al. [59] concluded that although the cytoskeleton is primarily responsible for $\mathrm{Pb} / \mathrm{Cu}$-associated toxicity in plants, it can also be responsible for the tolerance. To date, there are few studies examining the behavior of the cytoskeleton against high concentrations of $\mathrm{Cu}$ in plants, but this behavior can represent a target mechanism to search in potential plants oriented to the remediation by using PTE-phytostabilization. For this reason, it is necessary to continue investigating and integrating molecular and microscopic techniques to elucidate whether the cytoskeleton is indeed acting as an (indirect) mechanism of $\mathrm{Cu}$ tolerance, but also representing an efficient mechanism for the PTE stabilization in root organs of metallophyte.

\section{Materials and Methods}

\subsection{Plant Material and Experimental Design}

Rhizomes of I. cylindrica were collected in the Puchuncaví Valley (Central Chile, $32^{\circ} 4603000 \mathrm{~S}, 71^{\circ} 2801700 \mathrm{~W}$ ), Valparaíso Region, Chile, about $1.5 \mathrm{~km}$ from the Ventanas $\mathrm{Cu}$-smelter. The rhizomes were cut and disinfected with $2 \% w / v$ chloramine-T solution for $5 \mathrm{~min}$, then rinsed thoroughly with distilled water. Sterile-inert substrate was used for 
sprouting rhizomes, which was composed of sand and vermiculite $(9: 1 ; v / v)$. Plantlets were grown in a greenhouse for 6 months at $16 / 8 \mathrm{~h}$ light/dark photoperiod, at $25 \pm 3 / 15 \pm 3{ }^{\circ} \mathrm{C}$ day/night temperatures, and watering with sterile distilled water. The substrate was washed and sterilized by autoclaving per three consecutive days and air-dried for $24 \mathrm{~h}$. After sterilization, the sand/vermiculite mixture was supplemented with the equivalent to $200 \mathrm{~mL}$ of a solution of $5.9 \mathrm{~g} \mathrm{~L}^{-1}$ of $\mathrm{CuSO}_{4} \cdot 5 \mathrm{H}_{2} \mathrm{O}$, which was allowed to equilibrate for 2 weeks at room temperature, as described by Aponte et al. [2]. This substrate represented the treatment with a nominal equivalent of $300 \mathrm{mg} \mathrm{Cu} \mathrm{kg}^{-1}$. For the control treatment, $200 \mathrm{~mL}$ of distilled water were added to the substrate and let to equilibrate for 2 weeks. The assay compiled treatments with $300 \mathrm{mg} \mathrm{Cu} \mathrm{kg}^{-1}$ substrate and controls without $\mathrm{Cu}$ addition, which were performed in pots with three plants per pot and four experimental units per treatment $(n=4)$. A basal fertilization of 18,8 , and $8 \mathrm{mg} \mathrm{kg}^{-1}$ of $\mathrm{N}, \mathrm{P}$, and K, respectively, was applied to all plots using a commercial fertilizer (Vitasac 18-8-8, Anasac Ambiental S.A., Santiago, Chile). After 6 months of growth, the plants were incorporated to the described treatments. To measure the genetic response associated to $\mathrm{Cu}$ tolerance mechanisms in I. cylindrica, the controls and treatments were grown in a greenhouse under the conditions described above for 21 days after the $\mathrm{Cu}$ application, based on previous reports by Vidal et al. [20]. After this period, the plants were harvested, separated into shoots and root organs (roots and rhizomes), weighed, and immediately frozen at $-80{ }^{\circ} \mathrm{C}$ for further RNA extraction.

\subsection{Cu Localization in Plant Tissues}

In order to localize the $\mathrm{Cu}$-bound to the shoot and root tissues, plants with 21 days of growth were observed by Variable Pressure Scanning Electron Microscope (VP-SEM), with transmission module STEM SU-3500 (Hitachi, Tokyo, Japan). The presence of Cu was verified by Energy Dispersive X-Ray Spectrometer Detector (EDX), QUANTAX 100 (Bruker, Karlsruhe, Germany) with BSE detector in transversal sections of shoot and root (rhizome). The analyses were carried out in the Scientific and Technological Bioresource Nucleus (BIOREN, Universidad de La Frontera, Temuco, Chile). Additionally, root and shoot tissues were dried, grounded, converted into ashes, and digested in a mix of $\mathrm{dH}_{2} \mathrm{O}$ :concentrated $\mathrm{HCl}$ :concentrated $\mathrm{HNO}_{3}, 8: 1: 1$ v:v:v, and the $\mathrm{Cu}$ was measured by atomic absorption spectroscopy (AAS; Unicam SOLAAR, mod. 969, Cambridge, UK).

\subsection{RNA-Extraction, Sequencing, and De novo Transcriptome Assembly}

Total RNA was extracted from frozen samples of shoots and roots using E.Z.N.A ${ }^{\circledR}$ Total RNA Kit (Omega Bio-Tek, Norcross, GA, USA), according to the manufacturer's instructions. A total of 16 RNA extractions (two tissues [shoot and root] $\times$ two treatments [with and without $\mathrm{Cu}$ ] $\times$ four biological replicates) were performed, and the products were sent to Macrogen Inc, Korea, for sequencing. The quality and quantity in all the RNA extractions were checked using an Agilent Technologies 2100 Bioanalyzer (USA), where an RNA Integrity Number (RIN) value greater than or equal to 7 was adequate to perform the cDNA library construction. For each total RNA sample, a library of cDNA was constructed using TruSeq stranded kit (Illumina Inc., San Diego, CA, USA). Fifteen libraries were sequenced in an Illumina NovaSeq 6000 platform for 150 cycles in paired-end mode. The resulting FASTQ files containing the sequencing output were processed with NGSQC Toolkit [60] to evaluate the overall quality of the reads. This tool was also used to remove adaptors and reads with a low content of high-quality bases, where sequences with less than $70 \%$ of high-quality bases were removed from downstream analyses, being defined as high-quality the bases with a q-score higher than 30. Due to the lack of a reference genome for I. cylindrica, we used a de novo approach using Trinity v2.9.1 for reconstructing the transcriptome. It uses de Bruijn graphs to reconstruct transcripts and their variants using an extensive K-mer search strategy [61]. To assess assembly integrity, a set of conserved orthologous contained in the Embryophyta OrthoDBv9 database were queried by similarity search to I. cylindrica assembled transcripts using BUSCO [62]. 


\subsection{Differential Gene Expression Analysis}

The relative abundance of each sample was calculated using RSEM v1.2.26 [63] and merged in a matrix. It was analyzed using Bioconductor package DESeq2 [64], where a significant variation in gene expression was defined by a False Discovery Rate (FDR) lower than 0.01 and a minimum fold change (FC) of 4 .

\subsection{Transcriptome Annotation Analysis}

All resulting genes were aligned into the UniProt/SwissProtKB database using BLAST+ with an e-value of $1 \times 10^{-10}$ as the threshold. Functional annotation and ontology assignments were performed using the PANTHER classification system [65] with gene lists obtained from blast results (top hit) aligned with reference proteome database (version 2018_4) from EMBL.

\section{Conclusions}

Differential expression analysis using the de novo transcriptome of Imperata cylindrica plants growing under $\mathrm{Cu}$ stress generated the identification of a large number of genes involved in the $\mathrm{Cu}$ tolerance response, especially in root organs. Our results strongly support the importance of the root organs of I. cylindrica as the main responsible for $\mathrm{Cu}$ tolerance and as a sink that ultimately produces the metal bioaccumulation. Moreover, some genes with structural function in the cytoskeleton are also proposed as an interesting mechanism for reducing the $\mathrm{Cu}$ toxicity, presumably through the $\mathrm{Cu}$-binding to actin microfilaments and microtubules. The latter is especially important if phytostabilization programs are planned using $\mathrm{Cu}$-tolerant metallophytes, in which case I. cylindrica emerges as an ideal candidate. Nevertheless, more in-deep studies are necessary to validate this hypothesis.

Author Contributions: Conceptualization, C.V. and P.C.; methodology, C.V. and G.L.; software, G.L. and A.R.; validation, C.V. and G.L.; formal analysis, C.V., G.L., and A.R.; investigation, C.V. and P.C.; data curation, C.V. and G.L.; writing-original draft preparation, C.V.; writing-review and editing, P.C. and C.M.; supervision, P.C. and C.M.; funding acquisition, P.C. All authors have read and agreed to the published version of the manuscript.

Funding: This research was funded by ANID/FONDECYT/1170264, ANID/FONDAP/15130015, and ANID/PIA-ANILLO/ACM170002 from the Agencia Nacional de Investigación y Desarrollo, Chile. C. Vidal thank to ANID/Doctoral Fellowship No. 21150788.

Institutional Review Board Statement: Not applicable.

Informed Consent Statement: Not applicable.

Data Availability Statement: Data available on request due to restrictions eg privacy or ethical. The data presented in this study are available on request from the corresponding author. The data are not publicly available due to the size and format of the files.

Conflicts of Interest: The authors declare no conflict of interest.

\section{References}

1. Chandrasekaran, A.; Ravisankar, R.; Harikrishnan, N.; Satapathy, K.K.; Prasad, M.V.R.; Kanagasabapathy, K.V. Multivariate statistical analysis of heavy metal concentration in soils of Yelagiri Hills, Tamilnadu, India? Spectroscopical approach. Spectrochim. Acta Part A Mol. Biomol. Spectrosc. 2015, 137, 589-600. [CrossRef]

2. Aponte, H.; Herrera, W.; Cameron, C.; Black, H.; Meier, S.; Paolini, J.; Tapia, Y.; Cornejo, P. Alteration of enzyme activities and functional diversity of a soil contaminated with copper and arsenic. Ecotox. Environ. Saf. 2020, 192, 110264. [CrossRef] [PubMed]

3. Cornejo, P.; Meier, S.; Borie, G.; Rillig, M.C.; Borie, F. Glomalin-related soil protein in a Mediterranean ecosystem affected by a copper smelter and its contribution to $\mathrm{Cu}$ and $\mathrm{Zn}$ sequestration. Sci. Total Environ. 2008, 406, 154-160. [CrossRef]

4. González, I.; Muena, V.; Cisternas, M.; Neaman, A. Copper accumulation in a plant community affected by mining contamination in Puchuncaví valley, central Chile. Rev. Chil. Hist. Nat. 2008, 81, 279-291.

5. Meier, S.; Borie, F.; Bolan, N.; Cornejo, P. Phytoremedition of metal-polluted soils by Arbuscular mycorrhizal fungi. Crit. Rev. Environ. Sci. Technol. 2012, 42, 741-775. [CrossRef]

6. Marschner, H. Marschner's Mineral Nutrition of Higher Plants; Academic Press: Cambridge, MA, USA, 2011.

7. Yruela, I. Copper in plants. Braz. J. Plant Physiol. 2005, 17, 145-156. [CrossRef] 
8. Ginocchio, R. Effects of a copper smelter on a grassland community in the Puchuncaví Valley, Chile. Chemosphere 2000, 41, 15-23. [CrossRef]

9. Ortiz, J.; Soto, J.; Almonacid, L.; Fuentes, A.; Arriagada, C. Alleviation of metal stress by Pseudomonas orientalis and Chaetomium cupreum strains and their effects on Eucalyptus globulus growth promotion. Plant Soil 2019, 436, 449-461. [CrossRef]

10. Silambarasan, S.; Logeswari, P.; Valentine, A.; Cornejo, P.; Kannan, V.R. Pseudomonas citronellolis strain SLP6 enhances the phytoremediation efficiency of Helianthus annuus in copper contaminated soils under salinity stress. Plant Soil 2020, 457, 241-253. [CrossRef]

11. Vara, M.N.; Oliveira, H.M. Metal hyperaccumulation in plants: Biodiversity prospecting for phytoremediation technology. Electron. J. Biotechnol. 2003, 6, 285-310.

12. Ginocchio, R. Solución vegetal. Induambiente 2004, 67, 30-32.

13. Amils, R.; Rodriguez, N.; de la Fuente, V. Composition, speciation and distribution of iron minerals in Imperata cylindrica. Plant Physiol. Biochem. 2007, 20, 1-6. [CrossRef] [PubMed]

14. Rodríguez, N.; Menéndez, N.; Tornero, J.; Amils, R.; De La Fuente, V. Internal iron biomineralization in Imperata cylindrica, a perennial grass: Chemical composition, speciation and plant localization. New Phytol. 2005, 165, 781-789. [CrossRef] [PubMed]

15. Villaseñor, I.M.; Lamadrid, M.R. Comparative anti-hyperglycemic potentials of medicinal plants. J. Ethnopharmacol. 2006, 104, 129-131. [CrossRef]

16. Chikoye, D.; Manyong, V.M.; Ekeleme, F. Characteristics of speargrass (Imperata cylindrica) dominated fields in West Africa: Crops, soil properties, farmer perceptions and management strategies. Crop Prot. 2000, 19, 481-487. [CrossRef]

17. MacDonald, G.E. Cogongrass (Imperata cylindrica)—Biology, Ecology, and Management. Crit. Rev. Plant Sci. 2004, 23, 367-380. [CrossRef]

18. Syarif, H.; Abu Bakar, M.S.; Yang, Y.; Neeranuch, P.; Bridgwater, A.V. Characterisation and Py-GC/MS analysis of Imperata cylindrica as potential biomass for bio-oil production in Brunei Darussalam. J. Anal. Appl. Pyrolysis 2018, 134, 510-519.

19. Meier, S.; Borie, F.; Curaqueo, G.; Bolan, N.; Cornejo, P. Effects of arbuscular mycorrhizal inoculation on metallophyte and agricultural plants growing at increasing copper levels. Appl. Soil Ecol. 2012, 61, 280-287. [CrossRef]

20. Vidal, C.; Ruiz, A.; Ortiz, J.; Larama, G.; Perez, R.; Santander, C.; Ferreira, P.A.A.; Cornejo, P. Antioxidant Responses of Phenolic Compounds and Immobilization of Copper in Imperata cylindrica, a Plant with Potential Use for Bioremediation of $\mathrm{Cu}$ Contaminated Environments. Plants 2020, 9, 1397. [CrossRef]

21. Peñarrubia, L.; Romero, P.; Carrió-Seguí, A.; Andrés-Bordería, A.; Moreno, J.; Sanz, A. Temporal aspects of copper homeostasis and its crosstalk with hormones. Front. Plant Sci. 2015, 6, 1-18. [CrossRef]

22. Silver, S.; Misra, T.K. Plasmid-mediated Heavy Metal Resistances. Annu. Rev. Microbiol. 1988, 42, 717-743. [CrossRef] [PubMed]

23. Petit, C.; van de Geijn, S. In vivo measurement of cadmium (115mCd) transport and accumulation in the stems of intact tomato plants (Lycopersicon esculentum, Mill.). Planta 2004, 138, 137-143. [CrossRef]

24. Sharma, S.; Dietz, K. The significance of amino acids and amino acid-derived molecules in plant responses and adaptation to heavy metal stress. J. Exp. Bot. 2006, 57, 711-726. [CrossRef]

25. Bernal, M.; Sánchez-Testillano, P.; Risueño, M.; Yruela, I. Excess copper induces structural changes in cultured pho-tosynthetic soybean cells. Funct. Plant Biol. 2006, 33, 1001. [CrossRef]

26. Peng, H.; He, X.; Gao, J.; Ma, H.; Zhang, Z.; Shen, Y.; Pan, G.; Lin, H. Transcriptomic changes during maize roots development responsive to Cadmium (Cd) pollution using comparative RNAseq-based approach. Biochem. Biophys. Res. Commun. 2015, 464, 1040-1047. [CrossRef]

27. Guan, Q.; Yu, J.; Zhu, W.; Yang, B.; Li, Y.; Zhang, L.; Tian, J. RNA-Seq transcriptomic analysis of the Morus alba L. leaves exposed to high-level UVB with or without dark treatment. Gene 2018, 645, 60-68. [CrossRef]

28. Jia, D.; Chen, H.; Mao, Q.; Liu, Q.; Wei, T. Restriction of viral dissemination from the midgut determines incompetence of small brown planthopper as a vector of Southern rice black-streaked dwarf virus. Virus Res. 2012, 167, 404-408. [CrossRef]

29. Puglisi, I.; Faedda, R.; Sanzaro, V.; Lo Piero, A.; Petrone, G.; Cacciola, S.O. Identification of differentially expressed genes in response to mercury I and II stress in Trichoderma harzianum. Gene 2012, 506, 325-330. [CrossRef]

30. Lillo, F.; Ginocchio, R.; Ulriksen, C.; Dovletyarova, E.A.; Neaman, A. Evaluation of connected clonal growth of Solidago chilensis as an avoidance mechanism in copper-pollutedsoils. Chemosphere 2019, 230, 303-307. [CrossRef]

31. Zhang, D.; Li, C. Genotypic differences and glutathione metabolism response in wheat exposed to copper. Environ. Exp. Bot. 2019, 157, 250-259. [CrossRef]

32. Shabbir, Z.; Sardar, A.; Shabbir, A.; Abbas, G.; Shamshad, S.; Khalid, S.; Natasha, N.; Murtaza, G.; Dumat, C.; Shahid, M. Copper uptake, essentiality, toxicity, detoxification and risk assessment in soil-plant environment. Chemosphere 2020, $259,127436$. [CrossRef] [PubMed]

33. Zlobin, I.E.; Kartashov, A.V.; Shpakovski, G.V. Different roles of glutathione in copper and zinc chelation in Brassica napus roots. Plant Physiol. Biochem. 2017, 118, 333-341. [CrossRef] [PubMed]

34. Ghazaryan, K.; Movsesyan, H.; Ghazaryan, N.; Watts, B.A. Copper phytoremediation potential of wild plant species growing in the mine polluted areas of Armenia. Environ. Pollut. 2019, 249, 491-501. [CrossRef]

35. Blanche, C.; Doelsch, E.; Keller, C.; Cazevieille, P.; Tella, M.; Chaurand, P.; Panfili, F.; Hazemann, J.-L.; Meunier, J.D. Evidence of sulfur-bound reduced copper in bamboo exposed to high silicon and copper concentrations. Environ. Pollut. 2014, 187, 22-30. 
36. Xu, C.; Chen, X.; Duan, D.; Peng, C.; Le, T.; Shi, J. Effect of heavy-metal-resistant bacteria on enhanced metal uptake and translocation of the Cu-tolerant plant, Elsholtzia splendens. Environ. Sci. Pollut. Res. Int. 2014, 22, 5070-5081. [CrossRef]

37. Lu, L.; Xie, R.; Liu, T.; Wang, H.; Hou, D.; Du, Y.; He, Z.; Yang, X.; Sun, H.; Tian, S. Spatial imaging and speciation of Cu in rice (Oryza sativa L.) roots using synchrotron-based X-ray microfluorescence and X-ray absorption spectroscopy. Chemosphere 2017, 175, 356-364. [CrossRef]

38. Shi, S.; Richardson, A.E.; O'Callaghan, M.; De Angelis, K.M.; Jones, E.E.; Stewart, A.; Firestone, M.K.; Condron, L.M. Effects of selected root exudate components on soil bacterial communities. FEMS Microbiol. Ecol. 2011, 77, 600-610. [CrossRef]

39. Howarth, J.R.; Parmar, S.; Barraclough, P.B.; Hawkesford, M.J. A sulphur deficiency-induced gene, sdi1, involved in the utilization of stored sulphate pools under sulphur-limiting conditions has potential as a diagnostic indicator of sulphur nutritional status. Plant Biotechnol. J. 2009, 7, 200-209. [CrossRef]

40. Lira, J.; Valenzuela, M.; Islas, M.; Osuna, T.; López, J.; Sañudo, J. Proteínas trasportadoras de fósforo de la familia PHT1 y su uso potencial en la agricultura moderna. REMEXCA 2019, 10, 1111-1123. [CrossRef]

41. Ameh, T.; Sayes, C.M. The potential exposure and hazards of copper nanoparticles: A review. Environ. Toxicol. Pharmacol. 2019, 71, 103220. [CrossRef] [PubMed]

42. Jaime-Pérez, N.; Kaftan, D.; Bína, D.; Bokhari, S.N.H.; Shreedhar, S.; Küpper, H. Mechanisms of sublethal copper toxicity damage to the photosynthetic apparatus of Rhodospirillum rubrum. Biochim. Biophys. Acta (BBA)-Bioenerg. 2019, 1860, 640-650. [CrossRef]

43. Shahid, M.; Pourrut, B.; Dumat, C.; Nadeem, M.; Aslam, M.; Pinelli, E. Heavy-Metal-Induced Reactive Oxygen Species: Phytotoxicity and Physico-chemical Changes in Plants. Rev. Environ. Contam. Toxicol. 2014, 232, 1-44. [PubMed]

44. Quartacci, M.F.; Cosi, E.; Navari-Izzo, F. Lipids and NADPH-dependent superoxide production in plasma membrane vesi-cles from roots of wheat grown under copper deficiency or excess. J. Exp. Bot. 2001, 52, 77-84. [PubMed]

45. Apel, K.; Hirt, H. Reactive Oxygen Species: Metabolism, Oxidative Stress, and Signal Transduction. Annu. Rev. Plant Biol. 2004, 55, 373-399. [CrossRef] [PubMed]

46. Gong, Q.; Wang, L.; Dai, T.; Zhou, J.; Kang, Q.; Chen, H.; Li, K.; Li, Z. Effects of copper on the growth, antioxidant enzymes and photosynthesis of spinach seedlings. Ecotoxicol. Environ. Saf. 2019, 171, 771-780. [CrossRef] [PubMed]

47. Buapet, P.; Shah Mohammadi, N.; Pernice, M.; Kumar, M.; Kuzhiumparambil, U.; Ralph, P. Excess copper promotes photoinhibition and modulates the expression of antioxidant-related genes in Zostera muelleri. Aquat. Toxicol. 2018, 207, 91-100. [CrossRef]

48. Basu, U.; Good, A.G.; Taylor, G.J. Transgenic Brassica napus plants overexpressing aluminium-induced mitochondrial manganese superoxide dismutase cDNA are resistant to aluminium. Plant Cell Environ. 2001, 24, 1278-1269. [CrossRef]

49. Gronberg, C.; Sitsel, O.; Lindahl, E.; Gourdon, P.; Andersson, M. Membrane Anchoring and Ion-Entry Dynamics in P-type ATPase Copper Tra, ensport. Biophys. J. 2016, 111, 2417-2429. [CrossRef]

50. Andrés-Colás, N.; Sancenón, V.; Rodríguez-Navarro, S.; Mayo, S.; Thiele, D.J.; Ecker, J.R.; Puig, S.; Peñarrubia, L. The Arabidopsis heavy metal P-type ATPase HMA5 interacts with metallochaperones and functions in copper detoxification of roots. Plant J. 2006, 45, 225-236. [CrossRef]

51. Deng, F.; Yamaji, N.; Xia, J.; Ma, J.F. A member of the heavy metal P-type ATPase OsHMA5 is involved in xylem loading of copper in rice. Plant Physiol. 2013, 163, 1353-1362. [CrossRef]

52. Xie, Y.; Ye, S.; Wang, Y.; Xu, L.; Zhu, X.; Yang, J.; Feng, H.; Yu, R.; Karanja, B.; Gong, Y.; et al. Transcriptome-based gene profiling provides novel insights into the characteristics of radish root response to $\mathrm{Cr}$ stress with next-generation sequencing. Front. Plant Sci. 2015, 6, 202. [CrossRef] [PubMed]

53. Fagotti, A.; Di Rosa, I.; Simoncelli, F.; Pipe, R.K.; Panara, F.; Pascolini, R. The effects of copper on actin and fibronectin organization in Mytilus gallo-provincialis haemocytes. Dev. Comp. Immunol. 1996, 20, 383-391. [CrossRef]

54. Schroer, T.A. Microtubules don and doff their caps: Dynamic attachments at plus and minus ends. Curr. Opin. Cell Biol. 2001, 3, 92-96. [CrossRef]

55. Hepler, P.K.; Hush, J.M. Behavior of Microtubules in Living Plant Cells. Plant Physiol. 2016, 112, 455-461. [CrossRef] [PubMed]

56. Rodríguez-Serrano, M.; Pazmiño, D.; Sparkes, I.; Rochetti, A.; Hawes, C.; Romero-Puertas, M.; Sandalio, L. 2,4-Dichlorophenoxyacetic acid promotes S-nitrosylation and oxidation of actin affecting cytoskeleton and peroxisomal dynamics. J. Exp. Bot. 2014, 65, 4783-4793. [CrossRef] [PubMed]

57. Matozzo, V.; Ballarin, L.; Pamparin, D.M.; Marin, M.G. Effects of copper and cadmium exposure on functional responses of hemocytes in the clam, Tapes philippinarum. Arch. Environ. Contam. Toxicol. 2001, 41, 163-170. [CrossRef]

58. Jia, H.; Chen, S.; Wang, X.; Shi, C.; Liu, K.; Zhang, S.; Li, J. Copper oxide nanoparticles alter cellular morphology via disturbing the actin cytoskeleton dynamics in Arabidopsis roots. Nanotoxicology 2020, 14, 127-144. [CrossRef]

59. Xu, P.; Liu, D.; Jiang, W. Cadmium effects on the organization of microtubular cytoskeleton in interphase and mitotic cells of Allium sativum. Biol. Plant 2009, 53, 387-390. [CrossRef]

60. Patel, R.K.; Jain, M. NGS QC Toolkit: A Toolkit for Quality Control of Next Generation Sequencing Data. PLoS ONE 2012, 7, e30619. [CrossRef]

61. Grabherr, M.; Haas, B.; Yassour, M.; Levin, J.; Thompson, D.; Amit, I.; Adiconis, X.; Fan, L.; Raychowdhury, R.; Zeng, Q.; et al. Full-length transcriptome assembly from RNA-seq data without a reference genome. Nat. Biotechnol. 2011, 29, 644-652. [CrossRef]

62. Simao, F.A.; Waterhouse, R.M.; Ioannidis, P.; Kriventseva, E.V.; Zdobnov, E.M. BUSCO: Assessing genome assembly and annotation completeness with single-copy orthologs. Bioinformatics 2015, 31, 3210-3212. [CrossRef] [PubMed] 
63. Li, B.; Dewey, C.N. RSEM: Accurate transcript quantification from RNA-Seq data with or without a reference genome. BMC Bioinformatics 2011, 12, 323. [CrossRef]

64. Love, M.I.; Huber, W.; Anders, S. Moderated estimation of fold change and dispersion for RNA-seq data with DESeq2. Genome Biol. 2014, 15, 550. [CrossRef] [PubMed]

65. Mi, H.; Muruganujan, A.; Huang, J.X.; Ebert, D.; Mills, C.; Guo, X.; Thomas, P.D. Protocol Update for large-scale genome and gene function analysis with the PANTHER classification system (v.14.0). Nat. Protoc. 2019, 14, 703-721. [CrossRef] [PubMed] 